\title{
腎癌の予後規定因子としての原発巣と 転移巣の病理組織学的比較
}

\author{
横浜市立大学医学部泌尿器科学教室 (主任：穂坂正彦教授) \\ 福 田 百 邦
}

\section{A PATHOLOGICAL COMPARISON OF PRIMARY AND METASTATIC LESIONS AS A PROGNOSTIC INDICATOR FOR RENAL CELL CARCINOMA}

\author{
Momokuni Fukuda \\ Department of Urology, Yokohama City University, School of Medicine \\ (Director: Prof. M. Hosaka)
}

The purpose of this study is clarify the changes in histological grade between primary and metastatic lesions in renal cell carcinoma.

A tota of 100 cases of renal cell carcinoma and their metastases were compared respectively.

In $31(31 \%)$ of the cases observed, metastatic lesions were observed to have higher grade of malignancy when compared to primary lesions. In 59 (59\%) of the cases, metastatic lesions had the same grade of malignancy and in $10(10 \%)$ of the cases, metastatic lesions had a lower grade of malignancy when compared to primary lesions.

The frequency of upgrading cases in young patients (i.e. less than 40 years old) occurred with less frequency when compared to elderly patients.

Additionally, the frequency of upgrading cases invloving female patients was lower when compared to male patients.

The one year survival rates in patients, who received nephrectomy, having grade 1 to 4 lesions following metastases were $100 \%, 65 \%, 71 \%$, and $27 \%$ respectively. From these percentages, a stastically significant difference exists in one year survival rates between patients with grade 2 and 4 metastatic lesions $(\mathrm{p}<0.005)$, and grade 3 and 4 metastatic lesions $(\mathrm{p}<0.01)$.

Histological grade of metastatic lesions is an important prognostic indicator for determining the outcome of renal cell carcinoma following metastases. Thus it is important that the prognosis of renal cell carcinoma be based on the histological grade of metastatic lesions as well as primary lesions.

Key words: renal cell carcinoma, grade of metastatic lesions, prognosis

要旨：100例の腎癌の原発巣と転移巣の病理組織像について比較検討し, 以下の結論を得た。

1） 59 例 $(59.0 \%)$ で原発巣と転移巣の grade の一致を認めたが，31例（31.0\%）で転移により grade up が, 10例 $(10.0 \%)$ で grade down が観察された.

2) Grade の変化は転移発生時に生じるものと考えられるが，転移巣内で腫瘍が発育する過程で生じ る可能性も示唆された.

3）40歳以下の若年者では, grade up 症例が少なく，女性は男性に比較して grade up する頻度が少な い傾向であった。

4）原発巣が淡明細胞型のみの症例の転移巣には，紡鍾細胞型ないし多形細胞型は認められなかった。

5）腎摘症例で転移巣の grade 1 から 4 の転移出現後の 1 年生存率は，それぞれ，100\%，65\%，71\%， 
$27 \%$ であり, grade 2 と grade 4 間 $(\mathrm{p}<0.005)$ おおび grade 3 と grade 4 間 $(\mathrm{p}<0.01)$ には有意差 を認め, 転移巣の grade が，転移出現後の予後を決定する重要な因子であることが示された。

6）転移を有する患者の予後は，原発巣の grade に転移巣の grade も加味して考えることが望ましい. キーワード：腎癌，転移巣の異型度，予後

\section{緒 言}

腎癌は，初診時すでに30\%もの症例が転移を有 し ${ }^{12)}$ ，腎摘後の転移症例を加えると70\%以上に転移が

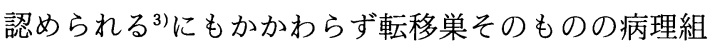
織学的検討や，転移出現後の生存期間を決定する因子 に関する検討はあまりなされていない.

今回，腎癌の原発巣および転移巣の病理組織像なら びに臨床経過を検討し，1）同一患者において，原発巣 の病理組織像が，転移により，どのように変化するの か, 特に原発巣の grade が, 転移により，いかなる grade に変化するのか, また, 転移のいかなる時期に変 化するのか，2）転移出現後の経過は, 転移巣の grade に左右されるかどうかの 2 点に関して検討した。

\section{対 象}

対象は, 横浜市大とその関連病院において1965年 1 月から1985年12月までに経験した腎癌症例550例中, 原 発巣, 転移巣とも病理組織学的に腎癌ならびに腎癌の 転移と診断された 100 例を対象とした，症例の内訳は， 男性72名,女性28名で男女比は, 2.6：1であり年齢は, 男性, 平均 60.1 歳, 女性, 平均 52.6 歳である.

原発巣および転移巣の採取方法は, 腎摘除術による もの 82 例, 転移巣手術によるもの 38 例, 病理解剖によ るもの52例，および転移巣手術，病理解剖両方による もの10例である。

転移巣に関して，免疫，化学，放射線療法等，何ら かの非観血的治療を施行したものは84例である.

\section{方法}

1）病理組織学的標本作製法

原発巣は, 割面において, 肉眼的に異なる数力所の 部分から組織片を切り出し, HE 染色にて，3 枚から 100枚（平均7.6枚）の標本を作製した。なお，1981年 以降の症例中15例は，著者らの独自の方法 ${ }^{4}$ によって 30 枚から 100 枚の全割面標本を作製した.

2) 病理組織学的分類法

組織学的構築型は，腎癌取扱い規約に従ったが，複 数の構築型が混在する症例では，その主要構築型を もって，その組織の構築型と判定した。また，複数の 構築型の占居面積がほぼ等しい場合は, これを併記し た.
組織学的細胞型についても, 腎癌取扱い規約に従つ たが，通常型における，淡明細胞型，顆粒細胞型，混 合型の分類は, 大西ら ${ }^{5} も$ 述べているように, 観察者に よって，その出現頻度に差があり，主観によるところ が大きい為, 今回は, 標本中に淡明細胞が大部分を占 めても，顆粒細胞が認められる場合，またはその逆の 場合は, 混合型と判定した。 その他の細胞型に関して は，その主要細胞型をもって，その組織の細胞型と判 定したが，複数の細胞型の占居面積がほぼ等しい場合 は，これを併記した。

組織学的異型度は, Hand and Broders 分類6をもと にした著者ら独自の 4 分類法7で行ない， 2 つ以上の 異なった grade の混在例は, 最も高い grade の部分を もってその標本の grade とした.この規準による grade 分類の妥当性は，既に報告した通り8である.

3）生存率の計算方法

生存率は, Kaplan-Meier の product-limit 推定法 ${ }^{9}$ の算定方法に従った。生存率の有意差検定には, Logrank test を用いた。転移出現後の生存期間の起算日 は転移巣発見日とした。なお, 初診時すでに転移を有 する症例については，特に，断りのないかぎり，転移 巣発見日を初診日とした。

\section{結 果}

1. 原発巣と転移巣との病理組織学的比較

100例の転移巣の部位別出現頻度を Table 1 に示し

Table 1 Metastatic sites in 100 cases with renal cell carcinoma

\begin{tabular}{l|r}
\hline \multicolumn{1}{c|}{ Metastatic sites } & No. (\%) \\
\hline Lung & $53(53.0)$ \\
Lymphnode & $46(46.0)$ \\
Adrenal gland & $26(26.0)$ \\
Kidney & $24(24.0)$ \\
Liver & $21(21.0)$ \\
Bone & $15(15.0)$ \\
Heart & $12(12.0)$ \\
Pancreas & $10(10.0)$ \\
Brain & $9(9.0)$ \\
Skin & $7(7.0)$ \\
Others & $50(50.0)$ \\
\hline
\end{tabular}


Table 2 Changes in structual type between primary and metastatic renal cell carcinoma

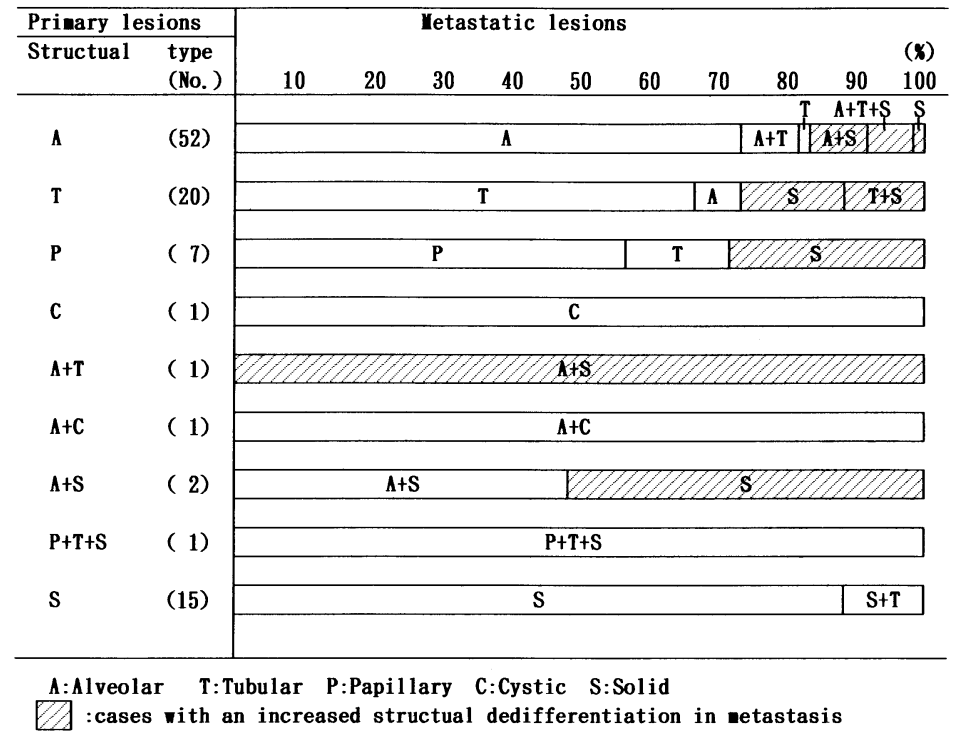

Table 3 Changes in cell type between primary and metastatic renal cell carcinoma

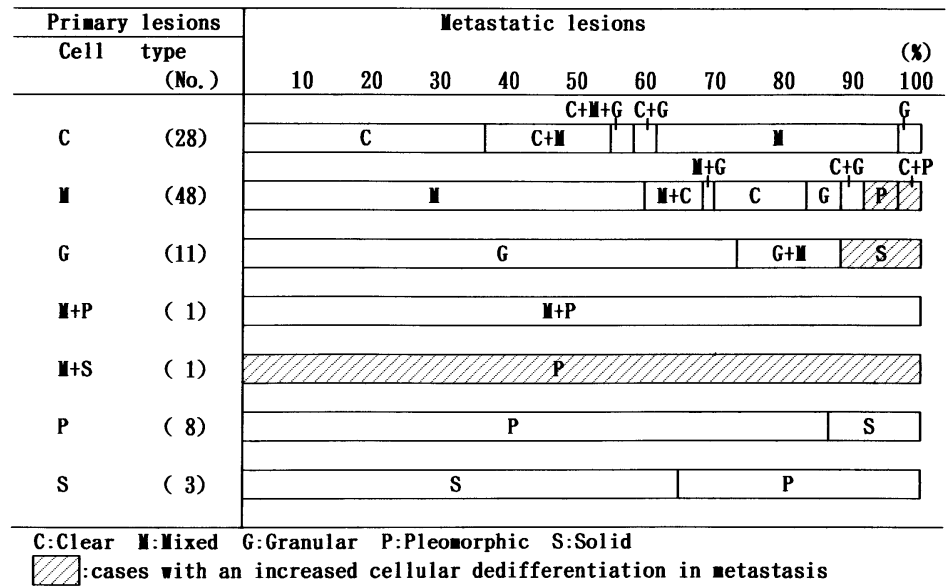

た。肺転移53例, リンパ節転移46例, 副腎転移26例等 であり,これら,のべ247の転移巣と原発巣とを病理組 織学的に比較検討した。

1) 組織学的構築型 (Table 2)

100例中75例 $(75.0 \%)$ で，原発巣と転移巣との組織 学的構築型の一致を認めた. 残りの 25 例 $(25.0 \%)$ は, 原発巣とは異なる組織学的構築型を示す転移巣を有す る症例であった。この25例中15例（15.0\%）は原発巣 が胞巣型，腺管型，乳頭型ないし囊胞型で，転移巣に
充実型が含まれる，すなわち構築上，転移により，低 分化傾向を示す症例であった。

一方，原発巣が充実型の15例は，1例を除き，転移 巣もすべて充実型であった。

2）組織学的細胞型（Table 3)

原発巣が通常型 (淡明細胞型, 顆粒細胞型, 混合型) の87例中 83 例 $(83.0 \%)$ が，転移巣も通常型を示した が，転移巣が，紡鍾細胞型ないし多形細胞型を示す症 例が， 4 例 $(4.0 \%)$ 認められ，細胞型の上からも，転 
Table 4 Changes in histological grade between primary and metastatic renal cell carcinoma

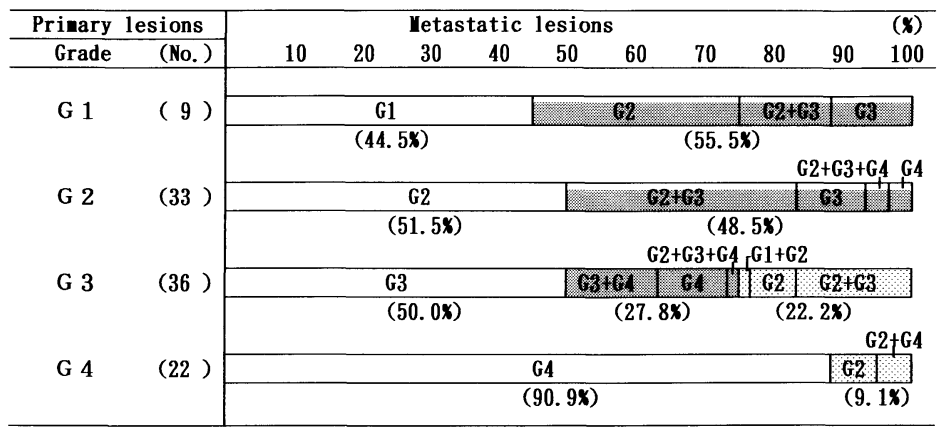

$\square$ :upgrading cases $\square$ :doungrading cases

Table 5 Comparison between primary and metastatic renal cell carcinoma. according to histological grade. These 15 cases were studied by making whole area histological sections.

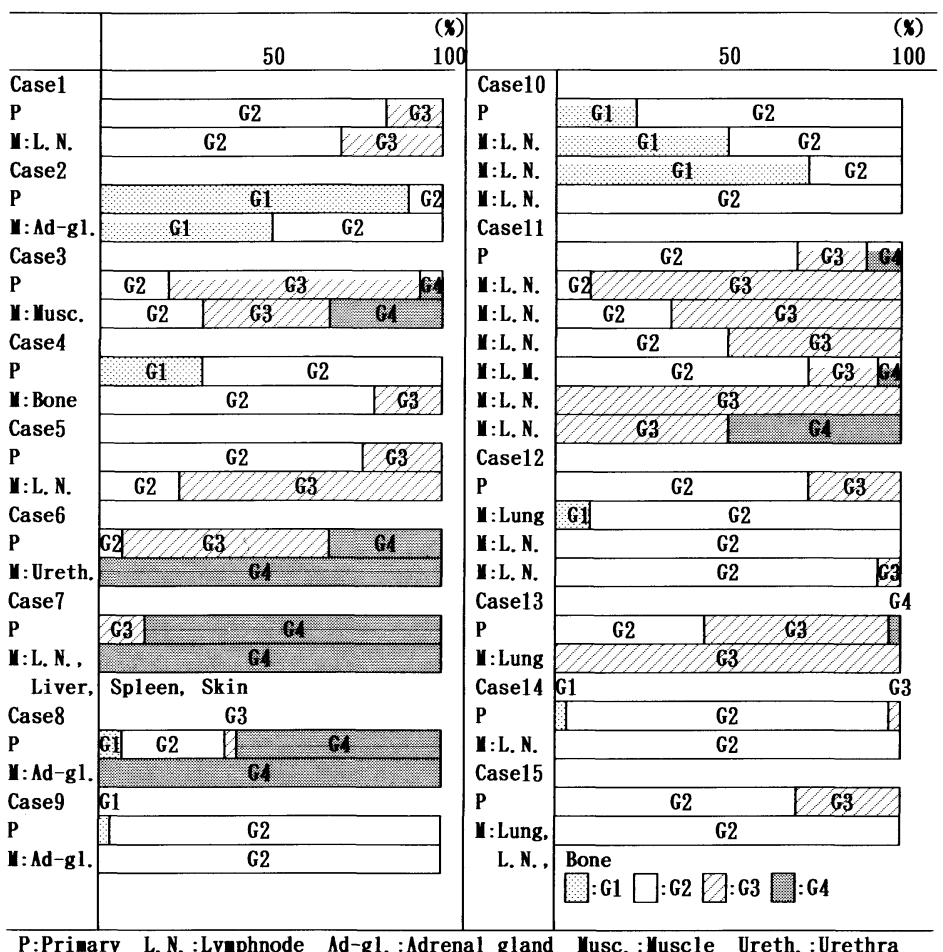

移により，低分化傾向を示す症例が存在する事を示す 結果であった．また，原発巣が純粋に淡明細胞型のみ の28例では，転移巣に紡鍾細胞型ないし多型細胞型を 示した症例は認められないという興味ある結果を示し た.

3) 組織学的異型度 (Table 4)
表の転移巣中, 十の症例は転移部位により grade の 異なる症例である。

原発巣と転移巣で grade が同一の症例は, 59例 (59.0\%)にすぎず, 原発巣より転移巣において, grade が高い部位が観察される症例が，31例（31.0\%）認め られ， $1 / 3$ 近い症例で, 転移により grade が上昇してい 
Table 6 Incidence of upgrading cases according to age, sex and tumor size of metastasis

\begin{tabular}{c|c|c|c|c|c|c|c|c}
\hline Age & No. & $(\%)$ & Sex & No. & $(\%)$ & Tumor size $(\mathrm{mm})$ & No. & $(\%)$ \\
\hline$\sim 40$ & $1 / 8$ & $(12.5)$ & $\mathrm{M}$ & $24 / 72$ & $(33.3)$ & $\sim 10$ & $58 / 157$ & $(36.9)$ \\
$41 \sim 50$ & $3 / 13$ & $(23.1)$ & & & & $11 \sim 20$ & $27 / 63$ & $(42.8)$ \\
$51 \sim 60$ & $15 / 40$ & $(37.5)$ & & & & $21 \sim 30$ & $9 / 25$ & $(36.0)$ \\
$61 \sim 70$ & $7 / 26$ & $(26.9)$ & & & & $31 \sim$ & $6 / 15$ & $(40.0)$ \\
$71 \sim$ & $4 / 13$ & $(30.8)$ & F & $6 / 28$ & $(21.4)$ & & & \\
\hline
\end{tabular}

\section{る部位があるという事実が観察された。}

また, grade 1の原発巣症例で, 転移巣が grade 4 に なった症例は認められなかった。

さらに，少数例ではあるが，10例 (10.0\%) では， 転移巣が原発巣よりも, grade が低いという結果で あった. Fig. 1 は, 最も高い転移巣の grade をその症 例の転移巣の grade と判定し, 原発巣と転移巣の grade の変化をシェーマにしたものである。転移によ り grade が上昇している症例が多いことが明らかで ある。

4) 原発巣が grade 混在例の転移巣（Table 5)

原発巣の grade 混在例では，転移巣がどのような grade の構成になるかという, 量的比較を, 原発巣の全 割面標本作製例15例で検討した。 なお, \%は, 腫瘍部に おける各 grade の占居率である。

15例全例，原発巣は grade 混在例であるが，その転 移巣は, 第 1 群：転移により grade の高い部分の占居 率が上昇するか, 原発巣にない, 高い grade が出現す る症例 9 例, 第 2 群：grade の高い部分の占居率が低 下ないし消失する症例 4 例, 第 3 群: 第 1 群および第 2 群両方が認められる症例 2 例の， 3 群に分類可能で あった。

5) Grade up の背景因子 (Table 6,7)

性差, 年齢, 転移巣の大きさ（最大径）に関して検 討したが，性別では，男性72例中 24 例(33.3\%)，女性 28例中 6 例 $(21.4 \%)$ で grade が上昇しており, 有意 差は認められないが，やや男性に多い傾向であった。 年齢別には，40歳以下の若年者では， 8 例中 1 例 (12.5\%)しか, grade が上昇せず, 若年者では, grade が上昇する頻度が低いという結果であった。転移巣の 大きさと, grade の上昇する頻度の間には, 特に相関関 係は認められなかった。転移部位では, リンパ節では, grade up が少なく，その他で示した. 比較的転移の少 ない部位で, 多い傾向が認められたが, ある特定の部 位で特に grade up するというような, 臟器特異性は認 められなかった。
Table 7 Localization of metastases and incidence of upgrading cases

\begin{tabular}{l|r|c|c|c|c}
\hline $\begin{array}{c}\text { Lccalization } \\
\text { of metastases }\end{array}$ & No. & $(\%)$ & $\begin{array}{c}\text { Localization } \\
\text { of metastases }\end{array}$ & No. & $(\%)$ \\
\hline Lung & $16 / 53$ & $(30.2)$ & Heart & $7 / 12$ & $(58.3)$ \\
Lymphnode & $7 / 46$ & $(15.2)$ & Pancreas & $3 / 10$ & $(30.0)$ \\
Adrenal gland & $8 / 26$ & $(30.8)$ & Brain & $3 / 9$ & $(33.3)$ \\
Kidney & $8 / 24$ & $(33.3)$ & Skin & $2 / 7$ & $(28.6)$ \\
Liver & $7 / 21$ & $(33.3)$ & Others & $22 / 50$ & $(44.0)$ \\
Bone & $5 / 15$ & $(33.3)$ & & & \\
\hline
\end{tabular}

Fig. 1 Schematic presentations of primary and metastatic renal cell carcinoma according to histological grade

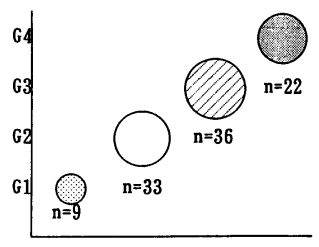

Primary lesions

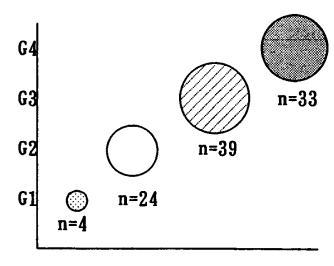

Metastatic lesions

\section{2. 転移巣の grade と臨床経過 (Fig. 2)}

転移出現後の, 転移巣の grade 別の遠隔成績を示し た。なお，異なる grade の転移巣を有する症例は，最 も高い転移巣の grade をもって, その症例の grade と した. また, 転移巣の手術療法例で NED となった症例 は転移巣がないという理由で，腎摘不能例は原発巣が 存在する等, 背景因子が異なるという理由で対象症例 から除外し，計65例で検討した。

転移巣の grade が 1 から 4 の 1 年生存率はそれぞ れ，100\%，65\%，71\%，27\%であり median survival は，それぞれ，40.0，18.5，18.0，4.0力月であった。

一方, 原発巣の grade が 1 から 4 の転移出現後の 1 年生存率はそれぞれ $100 \% ， 71 \% ， 48 \% ， 10 \%$ あり median survival は，それぞれ，24.0，21.0，13.0，2.0 カ月であった (Fig. 3).

転移巣の grade 2 と grade 3 は, 生存率にほとんど差 
Fig. 2 Survival time of patients after diagnosis of metastasis according to histological grade of metastatic lesions (by Kaplan-Meier's method)

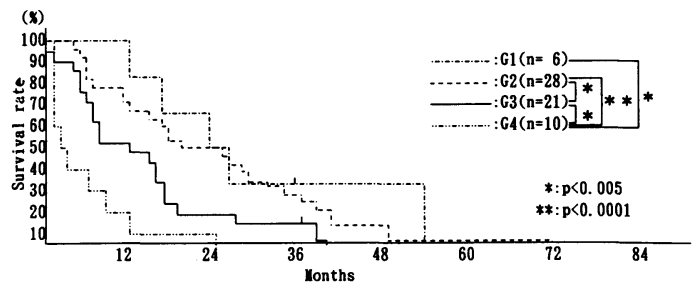

Fig. 3 Survival time of patients after diagnosis of metastasis according to histological grade of primary lesions (by Kaplan-Meier's method)

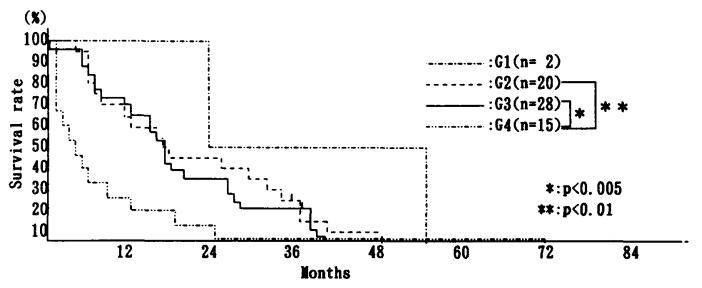

が認められないが, grade 4は grade $2(\mathrm{p}<0.005)$, grade $3 （ \mathrm{p}<0.01 ）$ に比較して有意に生存率が悪く, grade が上昇すると生存率が悪くなる傾向であり，転 移巣の grade が高い症例が低い症例よりも転移出現 後の経過は,より早いという結果が得られた。

Fig. 2 と Fig. 3 の比較では, grade up したために, Fig. 2 のほうがやや生存率が良好となっており，Fig. 3 すなわち, 原発巣の各 grade 間において, より生存率 の有意差を認め, Cox の比例ハザードモデルを用いた 検定でも，原発巣の grade のほうが，各期間で予後因 子としての重みが大きいという結果であった（Table 8).
Fig. 4 Survival time of patients with grade 1 primary lesions after diagnosis of metastasis according to grade of metastatic lesions (by Kaplan-Meier's method)

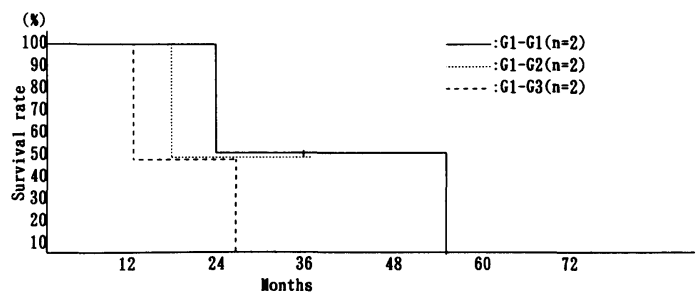

Fig. 5 Survival time of patients with grade 3 primary lesions after diagnosis of metastasis according to grade of metastasic lesions (by Kaplan-Meier's method)

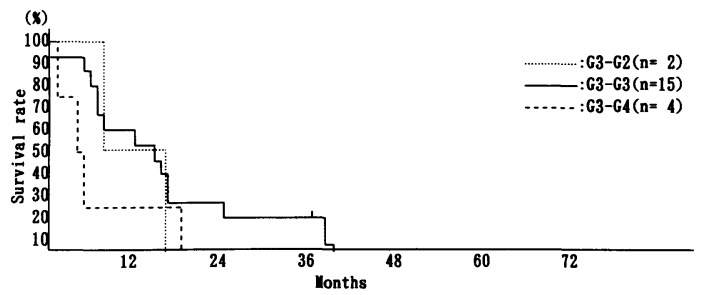

しかし, 少数例での検討ながら, 原発巣が同じ grade 1でも転移巣の grade が上昇すると予後不良の傾向が 認められ (Fig. 4), 同様の事が原発巣が grade 3で転

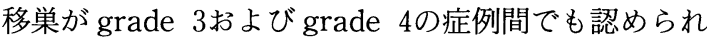
(Fig. 5), 転移巣の grade も, 転移出現後の生存期間を 決定する重要な因子であるという結果が得られた。

\section{考案}

腎癌の原発巣と転移巣とを病理組織学的に比較検討 した文献は少なく, 著者が調べ得た範囲では, 山田ら ${ }^{10)}$ が19例，Herman ら ${ }^{11}$ が 1 例 3 転移巣で検討し，転移

Table 8 Statistical analysis of the grade of primary and metastatic renal cell carcinoma, using Cox proportional hazard model

\begin{tabular}{c|c|c|c|c|c|c}
\hline \multirow{2}{*}{$\begin{array}{c}\text { Survival } \\
\text { time } \\
(\mathrm{M})\end{array}$} & \multicolumn{3}{|c|}{ Grade of primary RCC } & \multicolumn{3}{c}{ Grade of metastatic RCC } \\
\cline { 2 - 7 } & $\begin{array}{c}\text { Regression } \\
\text { coefficient } \\
\text { (b) }\end{array}$ & $\begin{array}{c}\text { Standard } \\
\text { error } \\
\text { (S.E.) }\end{array}$ & $\begin{array}{c}\text { t-value } \\
\text { (b/S.E.) }\end{array}$ & $\begin{array}{c}\text { Regression } \\
\text { coefficient } \\
\text { (b) }\end{array}$ & $\begin{array}{c}\text { Standerd } \\
\text { error } \\
\text { (S.E.) }\end{array}$ & $\begin{array}{c}\text { t-value } \\
\text { (b/S.E.) }\end{array}$ \\
\hline $0 \sim 9$ & -0.3055 & 0.0948 & $-3.223^{*}$ & 0.0483 & 0.1018 & 0.475 \\
$10 \sim 19$ & -0.2491 & 0.1009 & $-2.469^{*}$ & 0.0454 & 0.1083 & 0.419 \\
$20 \sim 29$ & -0.1021 & 0.0915 & -1.117 & -0.0797 & 0.0982 & -0.812 \\
$30 \sim 39$ & -0.1184 & 0.0782 & -1.514 & 0.0094 & 0.0840 & 0.112 \\
$40 \sim$ & -0.0237 & 0.0386 & -0.614 & 0.0019 & 0.0415 & 0.045 \\
\hline
\end{tabular}


により grade が上昇する傾向を述べているにすぎず， 今回のように, 100 例の多症例で, かつ, 臨床経過につ いても検討している文献は，見あたらない.

今回の検討で, 転移により, 約30\%の症例で grade up を, 約 $10 \%$ 症例で grade down を生じている転移 巣が存在する事が明らかになった。

このような grade の変化が，いつ，いかなる理由で 生ずるのか，すなわち，はじめから変化した細胞が転 移したのか, あるいは, 転移巣において変化が生じる のかについて検討した。

まず, grade up 症例については, Table 5 の第 1 群 中, 症例 6 から 9 の 4 例は, 原発巣が grade 混在例で 転移巣が原発巣中の最も高いgrade の部分と同じ grade だけで構成されており,しかも, その構築型拉よ び細胞型も一致ないし類似している事から, 原発巣中 の gradeの高い細胞が転移した結果と思われる。

しかし，転移巣において，腫瘍が発育する過程にお いて, grade up した可能性は否定できず，おなじ第 1 群中, 症例 1 から 5 の転移巣では, 転移巣も grade 混 在例であり，このことは，転移巣においても grade up が進行している結果と考えられる。そもそも，転移巣 において grade が混在するということは, 転移巣にお ける grade の変化を示唆するものと思われる.

すでに, 横路ら ${ }^{12)}$ が, 実験レベルで, 転移の過程で, 転移巣内で 1 つのクローンが優勢となる事を明らかに しており, ヒト腎癌においても, 転移巣内で, grade up することを指示するものと考えられる.

Grade down 症例に関しては, 腫瘍細胞が発育成長 していく中で, grade downしない13)という前提にた てば，転移により grade downしている症例は，原発 巣中の gradeの低い細胞が転移したものと考えられ る. 実際, Table 4 に示したように, 原発巣が grade 4 でありながら，転移巣が grade 2を示した症例も存在 し, grade 4の細胞が転移巣内で grade 2に変化したと は考えにくい.また, Table 5 に示した第 2 群は, 原 発巣よりも gradeの低い細胞の占居率が上昇してお り, 同様の理由で, 原発巣中の grade の低い細胞が転 移し，そこで progressionしたものと考えられる.

同一症例で転移部位により grade が異なる症例に ついては, 原発巣が grade 4でありながら, grade 4の 転移巣以外に grade 2 転移巣も存在し (Table 4), それぞれ grade 2 扔よび grade 4 の細胞が別個に転移 したものと考えられる。内藤ら ${ }^{13)}$ は, 腎癌において増 殖, 転移能の異なるクローンの分類に成功しており,
実際の症例においても, 異なるクローンがそれぞれ, 別個の転移巣を形成しても矛盾はないと考えられる.

以上より, 転移による gradeの変化は, 転移発生時 点で生じるものと考えられるが, 転移巣内で腫瘍が発 育する過程で生じる事も考えられ，2つの可能性が示 唆された.

また，治療により，転移巣の病理組織像に何らかの 変化が生ずる可能性については, 同一組織を継時的に 観察する事が, ほぼ不可能なため断言できないが, 生 検および病理解剖により, 同一部位から組織を得られ た 3 例においては, 2 例で病理組織像の一致を認めて おり, 他の 1 例でも若干, 病理解剖において異型度が 高い部分の占拠率が上昇しているものの, その組織学 的構築型および細胞型は, ほぼ完全に一致していた。 この事より，少なくとも治療効果のあまり得られない 症例においては, 治療による影響は, ほとんどないも のと推測される.

Grade 変化の背景因子として, 男性が女性より, grade が上昇例が多い傾向であったが，これは，女性が

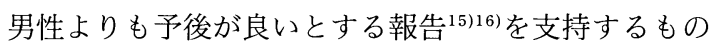
であり，ホルモン環境が転移の過程の上でも一要因と なっている可能性を示すものであるが, 詳細は不明で ある。

また, 若年者には, grade 上昇例が少ない傾向であっ たが，若年者では，転移が少なく予後は比較的良好で

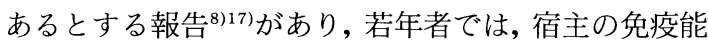
が高いことが何らかの因子になっているのではないか と推察される。

臨床経過に関しては, 転移巣の grade が高い症例が 低い症例よりも転移出現後の予後が悪いという結果が 得られた. Grade up 症例および grade down 症例を含 めると全症例の約 $40 \%$ となり, 転移出現後の予後を判 断するうえで, 原発巣の grade に転移巣の grade を加 味して検討することが重要であると考えられた。

\section{結語}

100例の腎癌の原発巣および転移巣を病理組織学的 に検討し, 次の結府を得た。

1）約 $60 \%$ の症例で，原発巣と転移巣の grade の一 致を認めたが, 約 $30 \%$ の症例が grade up 症例, 約 $10 \%$ の症例が, grade down 症例であった。

2) Grade の変化は, 転移発生時点で生じるものと 考えられるが, 転移巣内で腫瘍が発育する過程で生じ る可能性も示唆された.

3）若年者では, grade up 症例が少なく, 女性は, 
男性に比較して, grade up する頻度が少ない傾向で あった。

4）原発巣が淡明細胞型のみの症例の転移巣は細胞 型上，低分化傾向は認められなかった。

5）転移巣の grade が，転移出現後の予後を決定す る重要な因子であることが示された。

6）以上より，転移を有する患者の予後は，原発巣の grade のみならず，転移巣の grade も含めて考えるこ とが理想である。

稿を終えるにあたり, 御指導, 御校閲賜りました横浜市立 大学医学部泌尿器科学教室, 穂坂正彦教授, ならびに直接御 指導賜りました横須賀共済病院泌尿器科部長, 里見佳昭博 士，ほか関係各位に深謝いたします。

\section{文献}

1) Kantor, A.F.: Current conceptin the epidemiology and etiology of primary renal cell cercinoma. J. Urol., 117, 415-417, 1977.

2) deKernion, J.B., Ramming, K.P. and Smith, R. B.: The natural history of metastatic renal cell carcinoma : A computer analysis. J. Urol., 1, 148-152, 1978.

3) McNichols, D.W., Segura, J.W. and DeWeerd, J. H. : Renal cell carcinoma : Long-term survival and late recurrence. J. Urol., 126, 17-23， 1981.

4）仙賀 裕, 里見佳昭, 福田百邦, 絵鳩哲哉, 穂坂正 彦, 田中祐吉, 三杉和章：単クローン性抗 Leu-M1 抗体に上る腎細癌の免疫組織学的研究. 日泌尿会 誌，78，1246-1251，1987.

5）大西哲郎, 増田富士男, 町田豊平 : 腎細胞癌の病理 組織学的検討. 第 1 報。細胞型, 組織構築, 悪性度 について。 日泌尿会誌，74，967-976，1983.

6) Hand, J.R. and Broders, A.C.: Carcinoma of the kidney, the degree of malignancy in relation to factors bearing on prognosis. J. Urol., 28, 199-216, 1932.

7）里見佳昭, 高井修道, 近藤猪一郎, 岩崎孝一, 吉邑 貞夫, 福島修司, 古烟哲彦, 石塚栄一: 腎細胞癌の stage及び grade と予後. 日泌尿会誌，72，278
$-287,1981$.

8）里見佳昭, 福田百邦, 穂坂正彦, 近藤猪一郎, 吉邑 貞夫, 福島修司, 井田時雄, 広川 信, 森田 上, 古畑哲彦, 熊谷治巳, 塩崎 洋, 石塚栄一, 宮井啓 国, 仙賀 裕, 福岡 洋, 佐々木紘一, 公平昭男, 中橋 満: 腎癌の予後に関する臨床統計. 日泌尿 会誌，79，853-863，1988.

9) Kaplan, E.L. and Meier,P.: Nonparametric estimation from incomplete observations. J. Am. Stat. Assoc., 53, 457-481, 1958.

10）山田 泰, 上田豊史, 熊澤淨一：腎癌の臨床病理学 的検討一原発巣と転移巣の組織学的比較一. 西日 泌尿, 48, 1468, 1876.

11) Herrmann, W.R., Schobl, R., Meyer, W. and Dimmer, V.: Image processing in pathology. XII. Automated morphometry of tumor cell nuclei in hypernephroma: Comparison between renal tumor and metastasis. Exp. Path., 21, 71 $-78,1982$.

12）横路謙次郎, 丹羽太貫, 瀬山敏雄, 柳原五吉, 神谷 研二, 榎 悦孝, 新田由美子: 転移の細胞・分子機 構. Oncologia, 23, 40-46, 1990.

13）藤田哲也, 三沢信一：人癌自然史研究とその重要 性. Oncologia, 23, 5-14, 1990.

14）内藤誠二, 熊澤淨一， von Eschenbach, A.C. and Fidler, I.J. : 腎癌の heterogeneity に関する検討 一増殖・転移能について一. 泌尿器外科, 2, 161$165,1989$.

15）松㟝 理, 長尾孝一, 斎賀 一, 井坂茂夫, 島崎 淳, 五十嵐辰男, 村上信乃 : 若年者の腎細胞癌の特 徵。日病理会誌, 74, 412, 1985.

16) Castellanoss, R.D., Bernard, S.A. and Arthur. T. E.: Renal adenocarcinoma in children. Incidence, therapy and prognosis. J. Urol., 111, 534 $-537,1974$.

17）増田富士男：腎細胞癌の治療成績を左右する因子 一特に宿主側, 腫場側因子について一, 日泌尿会 誌，76，904-912， 1985. (1994年8月3日受付，1995年1月17日受理，特別揭載） 